\title{
Contractile Effects of Endothelins on Isolated Human Ureter
}

\author{
S. M. JANKOVIC ${ }^{1}$, S. V. JANKOVIC ${ }^{1}$, V. STOJANOVIC ${ }^{1}$, D. STOJADINOVIC ${ }^{2}$, \\ M. STOJADINOVIC ${ }^{2}$, D. CANOVIC ${ }^{3}$, S. STEFANOVIC ${ }^{1}$
}

${ }^{1}$ Pharmacology Department, Medical Faculty, University of Kragujevac, Kragujevac, Serbia, ${ }^{2}$ Urology and Nephrology Clinic, Clinical Center, Kragujevac, Serbia, ${ }^{3}$ Surgery Clinic, Clinical Center, Kragujevac, Serbia

Received December 23, 2010

Accepted June 28, 2011

On-line October 12, 2011

\section{Summary}

The aim of our study was to investigate mechanism of action of endothelins 1, 2 and 3 on spontaneous activity, tone and intraluminal pressure of human ureter. Both longitudinal tension and intraluminal pressure were recorded from the isolated segments of proximal human ureter. Endothelins 1, 2 and 3 $\left(5.35 \times 10^{-11} \mathrm{M}-5.05 \times 10^{-8} \mathrm{M}\right)$ produced concentration-dependent tonic contraction and sustained increase in intraluminal pressure of isolated preparations of human ureter. Endothelins 1 and 3 produced also concentration-dependent inhibition of spontaneous, phasic contractions of the isolated preparations. Selective antagonist of $\mathrm{ET}_{\mathrm{A}}$ receptors $\mathrm{BQ} 123$ and selective antagonist of $\mathrm{ET}_{\mathrm{B}}$ receptors $\mathrm{BQ788}$ produced significant inhibition of endothelin-1-induced tonic contraction $\left(\mathrm{pA}_{2}=8.80\right.$ and 6.55, respectively) and increase in intraluminal pressure $\left(\mathrm{pA}_{2}=8.68\right.$ and 7.02, respectively), while they did not affect endothelin-1induced inhibition of spontaneous activity. Endothelin 1 produces increase in tone and intraluminal pressure of isolated human ureter acting on both $\mathrm{ET}_{\mathrm{A}}$ and $\mathrm{ET}_{\mathrm{B}}$ receptors, the first one being functionally more important. Only endothelins 1 and 3 inhibit spontaneous, phasic activity of human ureter, but this effect was not blocked by selective antagonists of $\mathrm{ET}_{\mathrm{A}}$ and $\mathrm{ET}_{\mathrm{B}}$ receptors.

\section{Key words}

Endothelins • Human ureter • Intraluminal pressure • Smooth muscles

\section{Corresponding author}

S. M. Jankovic, Medical Faculty, University of Kragujevac, UI. Svetozara Markovica 69, 34000 Kragujevac, Serbia. Fax: +381 34 370073. E-mail: slobnera@eunet.rs

\section{Introduction}

The three 21-amino-acid signaling peptides: endothelin-1 (ET-1), endothelin-2 (ET-2), and endothelin-3 (ET-3), produce contraction of smooth muscles through activation of two $G$ protein-coupled receptor sub-types (ET-A and ET-B) (Brunner et al. 2006, Davenport and Maguire 2006, Polikepahad et al. 2006). $\mathrm{ET}_{\mathrm{A}}$ receptors have higher affinities for ET-1 and ET-2 than ET-3, while $\mathrm{ET}_{\mathrm{B}}$ receptors have the same affinities for ET-1, ET-2 and ET-3 (Huang 2005). Although endothelins primarily contract smooth muscles in blood vessels (Brunner et al. 2006), there are significant effects of these peptides on extravascular smooth muscles. Endothelins contract smooth muscles in esophagus, stomach, ileum, colon, gallbladder, common bile duct (Huang 2005), airways (Henry 1999), myometrium (Cameron et al. 1995) and Fallopian tubes (Jankovic et al. 2009).

Up to nowadays, it was shown in rabbit, human and canine urinary tract that ET-1 produces significant contractile responses of smooth muscle in bladder dome, trigone, and urethra (Langenstroer et al. 1997, OkamotoKoizumi et al. 1999, Wada et al. 2000), and immunohistochemistry studies in dogs located ET-1 to epithelial elements of these organs (Langenstroer et al. 1997). $\mathrm{ET}_{\mathrm{A}}$ receptors were found in rabbit and rat ureter by binding studies (Latifpour et al. 1995, Nakamura et al. 1997), and there are proofs that these receptors are upregulated in diabetes (Saito et al. 1999) and after ligation of ureter (Feldman et al. 2000). Although in a study on isolated human ureter contractile effect of 
endothelin-1 was demonstrated as part of the experimental protocol (Iselin et al. 1998), effects of other two endothelins were not investigated, and receptors for endothelins in human ureter were not characterized, leaving us without clear picture about role of endothelins in regulation of human ureter motility.

The aim of our study was to investigate effects of endothelins 1, 2 and 3 on spontaneous activity, tone and intraluminal pressure of isolated segment of human ureter, and to analyze receptors through which the most potent of them exerts its action.

\section{Materials and Methods}

\section{Patients}

Segments of ureter were taken from 17 patients (7 male and 10 female) during nephrectomy. All patients underwent surgery because of renal cell carcinoma in stage T1N0M0. The mean age of the patients was $61.75 \pm 10.12$ years, with the range from 42 to 69 years. The study was approved by Ethics Committee of Clinical Center "Kragujevac", and the patient signed the informed consent forms.

All patients underwent surgery from 2004 to 2007 in the Urology and Nephrology Clinic of Clinical Centre "Kragujevac" in Kragujevac, Serbia. The operations were performed under general anesthesia.

\section{Isolated preparations}

The segment of ureter $(6 \mathrm{~cm}$ long, starting $3 \mathrm{~cm}$ distal from pyeloureteral junction) taken from a patient in the operating room was transferred to the laboratory within the next 15 minutes, and there mounted in an isolated organ bath, according to modified method of Magnus (Magnus 1904). Distal end of the ureteral segment was tied at the bath bottom circumferentially, permitting entrance of a catheter in the lumen of the preparation; the catheter was used for measurement of intraluminal pressure. Proximal end of the ureteral segment was ligated, and hanged for isometric transducer.

\section{The bath and the transducer}

The isolated preparations were mounted in $75 \mathrm{ml}$ isolated organ bath, filled with Krebs solution (in $\mathrm{mM} / \mathrm{l}$ : $\mathrm{NaCl}$ 113.0, $\mathrm{KCl}$ 4.7, $\mathrm{CaCl}_{2} 2.5, \mathrm{MgSO}_{4} \times 7 \mathrm{H}_{2} \mathrm{O}$ 1.2, $\mathrm{NaHCO}_{3} 25.0, \mathrm{KH}_{2} \mathrm{PO}_{4} 1.2$ and glucose 11.6). The bath solution was maintained at $37{ }^{\circ} \mathrm{C}$ and aerated with $95 \%$ $\mathrm{O}_{2}$ and $5 \% \mathrm{CO}_{2}$. The longitudinal tension and the intraluminal pressure of the isolated preparations were continuously recorded with the isometric transducer (Palmer Bio Science, Los Angeles, CA, USA) and the pressure transducer (Majk Electronic, Mladenovac, Serbia), and registered on personal computer using Majk Electronic interface and software (Majk Electronic, Mladenovac, Serbia). The isolated preparations were given a passive load of $10 \mathrm{mN}$, and intraluminal pressure was set at $0.4 \mathrm{kPa}$; it was then allowed to equilibrate for $1 \mathrm{~h}$ before an experiment started.

\section{The agonists}

The effects of experimental substances on area under the contraction curve were measured. The AUC for tonic contractions was measured from the horizontal line which extrapolated the basal tone line (recorded before an agonist was added to the isolated organ bath) to the right, up to the line recorded after the agonist was added to the isolated organ bath, which connects the dips of phasic contractions. The AUCs of phasic contractions recorded after each agonist dose were summarized, and divided with time (in minutes) elapsed until addition of the next dose of the agonist.

The experimental substances were added to the isolated organ bath cumulatively, without washing between the subsequent doses, from serosal side of the isolated preparations. The interval between two adjacent doses was always 5-6 minutes. After cumulating all doses of an agonist, the bath was washed three times, and the isolated preparation was allowed to rest for further 30 minutes. In separate experiments, the antagonists were added to the bath 20 minutes before the agonists. The effect of each experimental substance was observed on at least four isolated preparations, taken from different individuals.

\section{Chemicals}

In this study the following substances were used: endothelin 1 human (Sigma-Aldrich, St. Louis, USA), endothelin 2 human (Sigma-Aldrich, St. Louis, USA), endothelin 3 human (Sigma-Aldrich, St. Louis, USA), selective antagonist of $\mathrm{ET}_{\mathrm{B}}$ receptors (Feldman et al. 2000) cis-2,6-dimethylpiperidinocarbonyl-g-methylleucyl -D-Trp(1- $\mathrm{CO}_{2} \mathrm{CH}_{3}$ )-D-Nle-OH (BQ788) (Sigma-Aldrich, St. Louis, USA), and selective antagonist of $\mathrm{ET}_{\mathrm{A}}$ receptors (Feldman et al. 2000) cyclo(D-Asp-L-Pro-DVal-L-Leu-D-Trp-) (BQ123) (Sigma-Aldrich, St. Louis, USA) (Davenport 2002).

For the purpose of the study, endothelin 1, endothelin 2, endothelin 3 and BQ123 were dissolved in 
distilled water, while BQ788 was dissolved in methanol.

\section{Statistics}

The concentration-response relationship was determined by linear regression on logarithmically transformed data calculated according to the method of least squares. The range of values used for the linear regression was from $15 \%$ to $85 \%$ of the maximal response, in the more linear part of the curve. The concentration of an agonist eliciting $50 \%$ of the maximum response $\left(\mathrm{EC}_{50}\right)$ and its confidence limits (1.96 x standard error) were determined graphically for each concentration-response curve by linear interpolation (Bowman and Rand 1980, Kenakin 1984).

The results are expressed as means $\pm 95 \%$ confidence intervals. Statistical differences between the $\mathrm{EC}_{50}$ of the control curve and $\mathrm{EC}_{50}$ in the presence of an antagonist were determined by Student's t-test for paired observations. A value of $p<0.05$ was considered to be statistically significant. The extent of an antagonist effect was expressed by $\mathrm{pA}_{2}$ value (-log molar concentration of antagonist reducing the agonist response by a factor of two), which was estimated from the Schild equation: $\left(\mathrm{EC}_{50} \mathrm{e} / \mathrm{EC}_{50} \mathrm{c}\right)-1=[\mathrm{B}] / \mathrm{K}_{\mathrm{b}}$, where $\mathrm{EC}_{50} \mathrm{e}$ is $\mathrm{EC}_{50}$ for the agonist in the presence of the antagonist, $\mathrm{EC}_{50} \mathrm{c}$ is $\mathrm{EC}_{50}$ for the agonist in the absence of the antagonist, [B] is concentration of the antagonist and $\mathrm{K}_{\mathrm{b}}$ is dissociation constant of the antagonist, which is further mathematically transformed to $\mathrm{pA} 2\left(\mathrm{pA} 2=-\log \mathrm{K}_{\mathrm{b}}\right)$ (Jankovic et al. 1999).

\section{Results}

\section{Spontaneous activity}

The isolated preparations of human ureter exhibited spontaneous activity which was simultaneously recorded as increase in longitudinal tension and in intraluminal pressure. The frequency of the spontaneous activity was $1.22 \pm 0.57$ per minute, with range from 0.55 to 2.68 per minute $(n=12)$. The area under the curve of spontaneous increase in longitudinal tension was $213.33 \pm 173.64 \mathrm{mN} / \mathrm{min}$ (range from 3.60 to $499.80 \mathrm{mN}$ / min; $\mathrm{n}=12$ ). The area under the curve of spontaneous increase in intraluminal pressure was $9.69 \pm 12.02 \mathrm{kPa} / \mathrm{min}$ (range from 0.31 to $37.12 \mathrm{kPa} / \mathrm{min} ; \mathrm{n}=12$ ).

The effects of endothelins on longitudinal tension of the isolated ureter

Endothelin-1 (from $5.35 \times 10^{-11} \mathrm{M}$ to $5.05 \times 10^{-8} \mathrm{M}$ ) produced concentration-dependent tonic contraction of the isolated ureter $\left(\mathrm{EC}_{50}=1.07 \pm 1.89 \times 10^{-9} \mathrm{M}\right.$; $\mathrm{r}=0.68$; $\mathrm{p}<0.01$ ) (Figs $1 \mathrm{~A}$ and $2 \mathrm{~A}$ ), and concentration-dependent inhibition of its spontaneous rhythmic contractions $\left(\mathrm{EC}_{50}=3.90 \pm 1.59 \times 10^{-9} \mathrm{M} ; \mathrm{r}=0.80 ; \mathrm{p}<0.05\right)$ (Fig. 1A). The maximal extent of endothelin-1 - induced tonic contraction was on average 994.46 $\pm 470.48 \mathrm{mN}$, and maximal extent of endothelin-1 - induced inhibition of spontaneous rhythmic contractions was $99.4 \pm 1.8 \%$.

Endothelin-2 (from $5.0 \times 10^{-11} \mathrm{M}$ to $4.94 \times 10^{-8} \mathrm{M}$ ) produced concentration-dependent tonic contraction of the isolated ureter $\left(\mathrm{EC}_{50}=4.99 \pm 1.84 \times 10^{-9} \mathrm{M} ; \mathrm{r}=0.88\right.$; $\mathrm{p}<0.001$ ) (Figs $1 \mathrm{~A}$ and 2B). However, endothelin-2 (from $5.0 \times 10^{-11} \mathrm{M}$ to $\left.4.94 \times 10^{-8} \mathrm{M}\right)$ did not influence spontaneous rhythmic contractions of the isolated ureter $(\mathrm{F}=0.83 ; \mathrm{r}=0.16 ; \mathrm{p}>0.05)$ (Fig. 1B). The maximal extent of endothelin-2 - induced tonic contraction was on average $360.12 \pm 333.85 \mathrm{mN}$.

Endothelin-3 (from $5.0 \times 10^{-11} \mathrm{M}$ to $4.76 \times 10^{-8} \mathrm{M}$ ) produced concentration-dependent tonic contraction of the isolated ureter $\left(\mathrm{EC}_{50}=3.90 \pm 12.34 \times 10^{-9} \mathrm{M} ; \mathrm{r}=0.65\right.$; $\mathrm{p}<0.05$ ) (Figs $1 \mathrm{~A}$ and $2 \mathrm{C}$ ), and concentration-dependent inhibition of its spontaneous rhythmic contractions $\left(\mathrm{EC}_{50}=3.05 \pm 0.31 \times 10^{-8} \mathrm{M} ; \mathrm{r}=0.67 ; \mathrm{p}<0.01\right)$ (Fig. 1C). The maximal extent of endothelin-3 - induced tonic contraction was on average $482.51 \pm 276.62 \mathrm{mN}$, and maximal extent of endothelin-3 - induced inhibition of spontaneous rhythmic contractions was $76.7 \pm 26.9 \%$.

The effects of endothelins on intraluminal pressure of the isolated ureter

Endothelin-1 (from $5.35 \times 10^{-11} \mathrm{M}$ to $5.05 \times 10^{-8} \mathrm{M}$ ) produced concentration-dependent sustained increase in intraluminal pressure of the isolated ureter $\left(\mathrm{EC}_{50}=2.03 \pm 1.41 \times 10^{-9} \mathrm{M} ; \mathrm{r}=0.83 ; \mathrm{p}<0.001\right)$ (Fig. 1A), and concentration-dependent inhibition of its spontaneous rhythmic increases in intraluminal pressure $\left(\mathrm{EC}_{50}=5.50 \pm 1.65 \times 10^{-9} \mathrm{M} ; \mathrm{r}=0.80 ; \mathrm{p}<0.01\right)$ (Fig. 1A). The maximal extent of endothelin-1 - induced sustained increase in intraluminal pressure was on average $66.79 \pm 51.91 \mathrm{kPa}$, and maximal extent of endothelin-1induced inhibition of spontaneous rhythmic increases in intraluminal pressure was $99.9 \pm 0.1 \%$.

Endothelin-3 (from $5.0 \times 10^{-11} \mathrm{M}$ to $4.76 \times 10^{-8} \mathrm{M}$ ) produced concentration-dependent sustained increase in intraluminal pressure of the isolated ureter $\left(\mathrm{EC}_{50}=1.17 \pm 2.81 \times 10^{-9} \mathrm{M} ; \mathrm{r}=0.62 ; \mathrm{p}<0.01\right)$ (Fig. 1C), and concentration-dependent inhibition of spontaneous rhythmic increases in intraluminal pressure 
$\left(\mathrm{EC}_{50}=3.74 \pm 3.19 \times 10^{-9} \mathrm{M} ; \mathrm{r}=0.62 ; \mathrm{p}<0.05\right)$ (Fig. 1C). The maximal extent of endothelin-3 - induced tonic contraction was on average $36.57 \pm 28.14 \mathrm{kPa}$, and maximal extent of endothelin-3 - induced inhibition of spontaneous rhythmic contractions was $96.7 \pm 6.7 \%$.

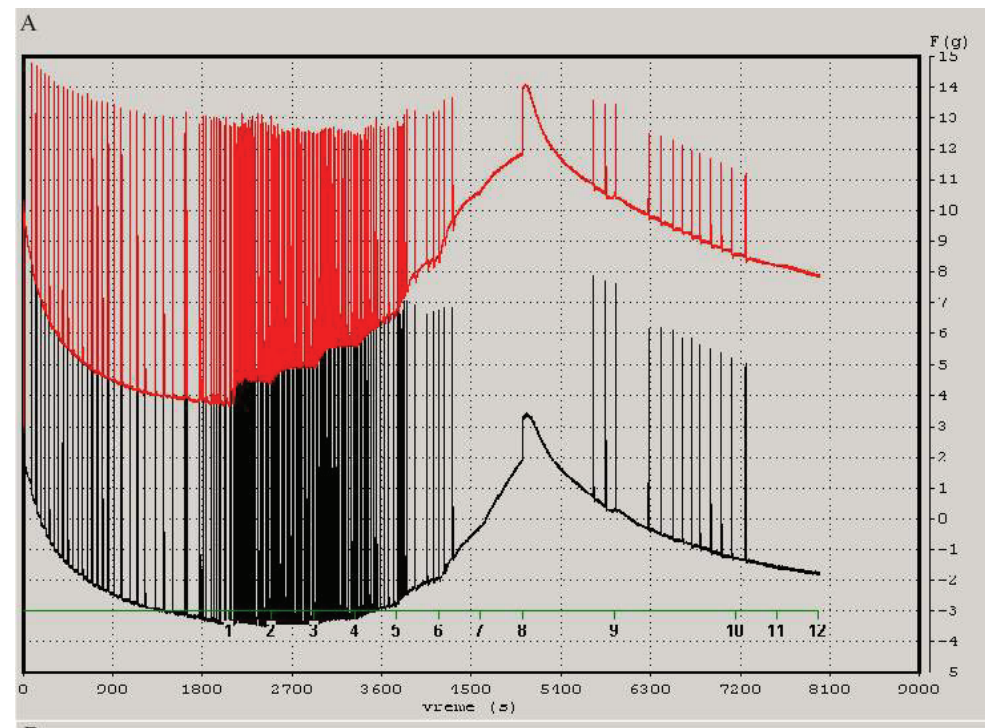

B

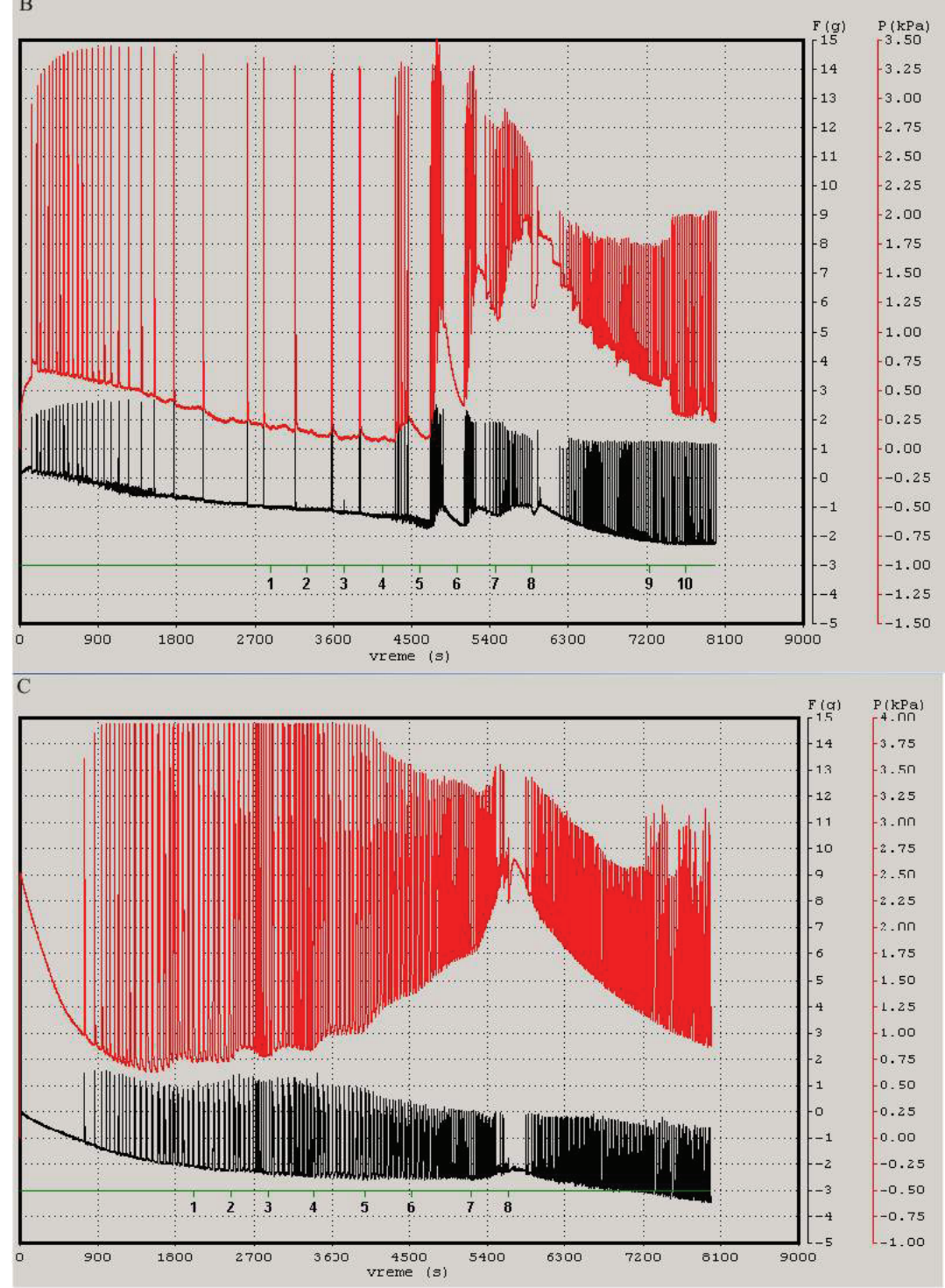

Fig. 1. Original tracings of effects of endothelin-1 (A), endothelin-2 (B) and endothelin-3 (C) on isolated human ureter tone, intraluminal pressure and spontaneous activity. $\mathrm{F}(\mathrm{g})=$ force (grams); $\mathrm{P}(\mathrm{kPa})=$ intraluminal pressure (kilopascals) vreme $(\mathrm{s})=$ time (seconds). Tracings in black - force of longitudinal contraction. Tracings in red intraluminal pressure. A - Numbers from 1 to 7 indicate addition of subsequent doses of endothelin-1. Number 8 indicates the bath washing. Number 9 indicate addition of BQ123, and numbers 10,11 and 12 addition of subsequent doses of endothelin-1. Note: continuation of this experiment with further doses of endothelin- 1 in the presence of the antagonist BQ123 are recorded at other tracing. B - Numbers from 1 to 7 indicate addition of subsequent doses of endothelin-2. Number 8 indicates the bath washing. Numbers 9 and 10 indicate addition of two doses of endothelin-1. Note: continuation of this experiment with further doses of endothelin-1 is recorded at other tracing. C Numbers from 1 to 7 indicate addition of subsequent doses of endothelin-3. Number 8 indicates the bath washing. 


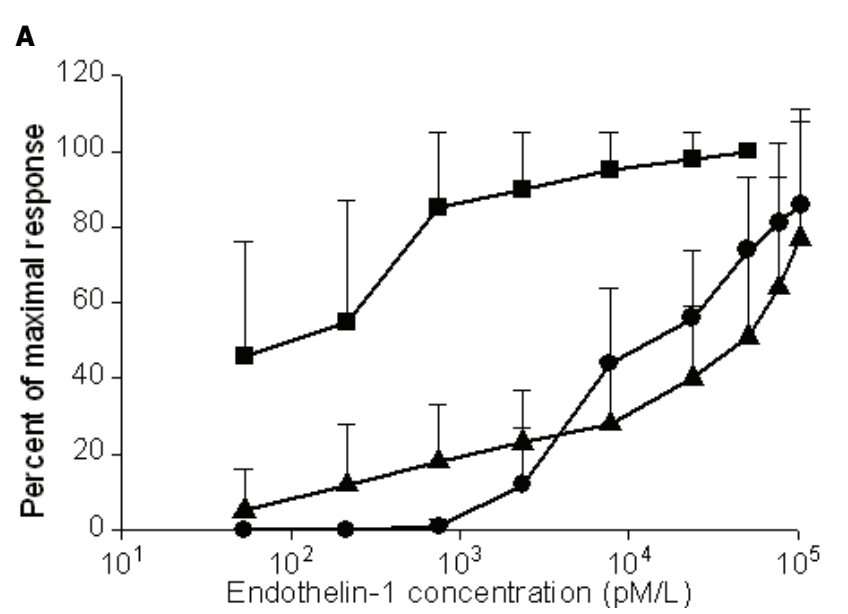

B

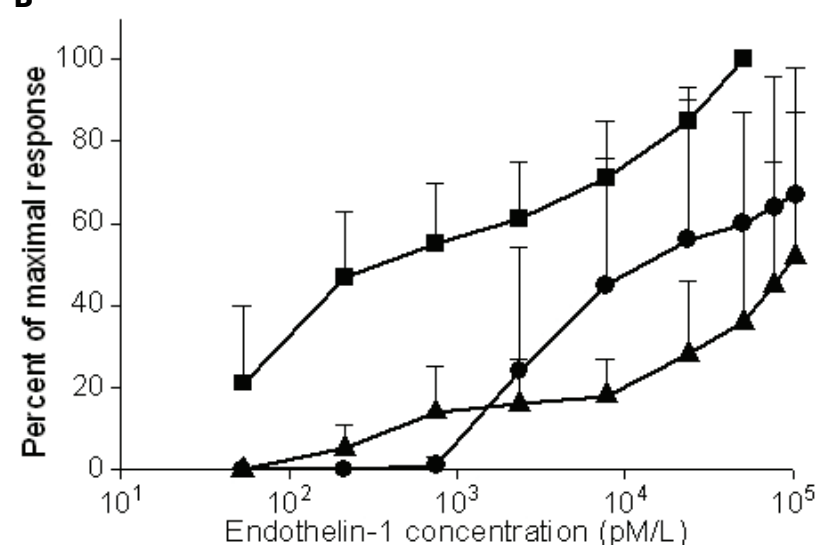

Fig. 2. Influence of selective antagonist of $E T_{A}$ receptors $B Q 123$ and selective antagonist of $\mathrm{ET}_{\mathrm{B}}$ receptors $\mathrm{BQ788}$ on endothelin-1 effects on longitudinal tone (A) and intraluminal pressure (B) of isolated segment of human ureter. Endothelin-1 ( $\mathbf{m}$, endothelin-1 + BQ788 $\left(1.0 \times 10^{-6} \mathrm{M}\right)(\bullet)$ and endothelin-1 + BQ123 (1.09 x $\left.10^{-6} \mathrm{M}\right)(\mathbf{\Delta})$. Each point is mean response of five to eight isolated preparations. Error bars: standard deviations around mean responses. One half of the error bars was omitted for the sake of clarity.

Influence of selective antagonist of $E T_{A}$ receptors $B Q 123$ and selective antagonist of $E T_{B}$ receptors $B Q 788$ on endothelin-1 effects on isolated human ureter

BQ123 (1.09) $\left.10^{-6} \mathrm{M}\right)$ produced significant inhibition of endothelin-1 effect on tone (T-test=11.23; $\mathrm{df}=75 ; \mathrm{p}<0.001 ; \mathrm{pA}_{2}=8.80$ ) (Fig. $2 \mathrm{~A}$ ) and of endothelin-1 effect on increase of intraluminal pressure $(\mathrm{T}$-test $=11.28$; $\mathrm{df}=75 ; \mathrm{p}<0.001 ; \mathrm{pA}_{2}=8.68$ ) (Fig. 2B). However, BQ123 $\left(1.09 \times 10^{-6} \mathrm{M}\right)$ did not influence inhibitory effects of endothelin-1 on spontaneous rhythmic contractions (T-test $=1.55 ; \quad \mathrm{df}=59 ; \mathrm{p}>0.05$ ) and on spontaneous rhythmic increases in intraluminal pressure (T-test $=0.31$; $\mathrm{df}=74 ; \mathrm{p}>0.05)$ of isolated human ureter.

BQ788 $\left(1.0 \times 10^{-6} \mathrm{M}\right)$ produced significant inhibition of endothelin-1 effect on tone (T-test=3.35; $\left.\mathrm{df}=58 ; \mathrm{p}<0.01 ; \mathrm{pA}_{2}=6.55\right)$ (Fig. $2 \mathrm{~A}$ ) and of endothelin-1 effect on increase of intraluminal pressure $(\mathrm{T}$-test $=3.77$; $\mathrm{df}=58 ; \mathrm{p}<0.01 ; \mathrm{pA}_{2}=7.02$ ) (Fig. 2B). However, BQ788 $\left(1.0 \times 10^{-6} \mathrm{M}\right)$ did not influence inhibitory effects of endothelin-1 on spontaneous rhythmic contractions ( $\mathrm{T}$-test $=1.22 ; \mathrm{df}=58 ; \mathrm{p}>0.05$ ) and on spontaneous rhythmic increases in intraluminal pressure $(\mathrm{T}$-test $=0.79$; $\mathrm{df}=58 ; \mathrm{p}>0.05$ ) of isolated human ureter.

Methanol $\left(62.5 \times 10^{-3} \mathrm{M}\right)$ did not influence effect of endothelin-1 on longitudinal tension ( $\mathrm{T}$-test $=0.58$; $\mathrm{p}>0.05$ ) and on intraluminal pressure (T-test $=0.34$; $\mathrm{p}>0.05$ ) of the isolated ureteral segment.

\section{Discussion}

Human ureter has smooth muscle layer with characteristics of a syncitium (Engelmann 1869, Bozler 1942), which easily transfers changes in membrane potentials from cell to cell. Spontaneously active cells in the renal pelvis generate electrical impulses, which are then conducted to ureteral smooth muscle cells. These impulses initiate contraction of the smooth muscle cells and formation of peristaltic waves which travel down the ureter and push urine to the bladder. Ureteral peristalsis is basically a myogenic process, which is then modulated by numerous nervous, endocrine and paracrine factors (Uehara and Burnstock 1970, Santicioli and Maggi 1998).

Endothelins are produced by different types of cells, including endothelial and epithelial cells, fibroblasts, macrophages, neurons (endothelin-1), intestinal epithelial cells (endothelin-2), and neurons and renal tubular cells (endothelin-3) (Pinet 2004). Endothelin-1 is involved in regulation of acid-base balance; its synthesis increases in renal tissue during metabolic acidosis, and it elevates expression of sodium/hydrogen $(\mathrm{Na}+/ \mathrm{H}+)$ transporter at luminal membrane of renal tubular cells (Laghmani et al. 2001, Peng et al. 2001), acting through $\mathrm{ET}_{\mathrm{B}}$ receptors. However, precise expression of endothelins and their receptors in ureter remains mostly unresolved; previous studies have confirmed existence of endothelin-1 immunoreactivity at canine and rabbit ureter, but without more detailed insight into its location and possible function (Latifpour et al. 1995, Langenstroer et al. 1997, Nakamura et al. 1997, Saito et al. 1999). The only study on human ureters in patients with renal cell carcinoma has shown that endothelin-1 caused contraction of isolated ureters, but it remained unclear whether this contraction was mediated by $\mathrm{ET}_{\mathrm{A}}, \mathrm{ET}_{\mathrm{B}}$ or non-ET $\mathrm{E}_{\mathrm{A}}$ 
non- $\mathrm{ET}_{\mathrm{B}}$ receptors; the effects of both endothelin-2 and endothelin-3 were not elucidated (Takeda et al. 1994).

Our results show strong, concentrationdependent contractile action of endothelin-1, endothelin-2 and endothelin-3 on human ureter; the contraction is tonic and accompanied by sustained increase in intraluminal pressure, suggesting possible role of endothelins in development of renal-ureteral colic. With exception of endothelin-2, endothelins also inhibit spontaneous, phasic contractions of ureter, which normally make basis of ureteral peristalsis. This further strengthens the assumption about possible role of endothelins in renalureteral colic, since after initial hyperperistalsis, peristaltic waves disappear, and pain is constant, due to sustained increase of intraluminal pressure proximal to the site of ureteral obstruction by stone or other solid material (Travaglini et al. 2004).

In our study selective antagonist of $\mathrm{ET}_{\mathrm{A}}$ receptors $\mathrm{BQ} 123$ and selective antagonist of $\mathrm{ET}_{\mathrm{B}}$ receptors $\mathrm{BQ788}$ produced significant inhibition of endothelin-1-induced tonic contraction and increase in intraluminal pressure, suggesting that both $\mathrm{ET}_{\mathrm{A}}$ and $\mathrm{ET}_{\mathrm{B}}$ receptors are involved in action of endothelins on ureteral smooth muscles. However, while $\mathrm{pA}_{2}$ value of $\mathrm{BQ} 123$ in the ureteral tissue was in the same range as $\mathrm{pA}_{2}$ values for the same antagonist observed in smooth muscles of Fallopian tubes (Jankovic et al. 2009, 2010), $\mathrm{pA}_{2}$ value of BQ788 in ureter was much lower than the values obtained in that tissue (the magnitude of difference was more than 2). Such results suggest functional predominance of $\mathrm{ET}_{\mathrm{A}}$ receptors, although $\mathrm{ET}_{\mathrm{B}}$ receptors are still important, and participate in the tissue response on endothelins. Endothelin-3 has higher affinity for $\mathrm{ET}_{\mathrm{B}}$ than for $\mathrm{ET}_{\mathrm{A}}$ receptors, and we have observed somewhat higher sensitivity of isolated human ureter to endothelin-3 than to other two endothelins (Fig. 1). Therefore, in order to completely abolish the effects of endothelin-1 on human ureter, dual blockade of $\mathrm{ET}_{\mathrm{A}}$ and $\mathrm{ET}_{\mathrm{B}}$ receptors is needed. Further research using different methods (binding studies, immunohistochemical studies and receptor expression studies) is necessary to characterize $\mathrm{ET}_{\mathrm{A}}$ and $\mathrm{ET}_{\mathrm{B}}$ receptors in more detail, and give complete insight in their physiological roles.

In conclusion, endothelins 1, 2 and 3 produce increase in tone and intraluminal pressure of isolated human ureter acting on both $\mathrm{ET}_{\mathrm{A}}$ and $\mathrm{ET}_{\mathrm{B}}$ receptors, the first one being functionally more important. Only endothelins 1 and 3 inhibit spontaneous, phasic activity of human ureter, but this effect is not mediated through conventional $\mathrm{ET}_{\mathrm{A}}$ and $\mathrm{ET}_{\mathrm{B}}$ receptors.

\section{Conflict of Interest}

There is no conflict of interest.

\section{Acknowledgements}

This study was partially funded through grant No 175007 , given by the Ministry of Science, Republic of Serbia.

\section{References}

BOWMAN WC, RAND MJ: Principles of Drug Action. In: Textbook of Pharmacology. BOWMAN WC, RAND MJ (eds), Blackwell Scientific Publication, Oxford, 1980, pp 1-46.

BOZLER E: The action potentials accompanying conducted responses in visceral smooth muscles. Am J Physiol 136: 552-560, 1942.

BRUNNER F, BRÁS-SILVA C, CERDEIRA AS, LEITE-MOREIRA AF: Cardiovascular endothelins: essential regulators of cardiovascular homeostasis. Pharmacol Ther 111: 508-531, 2006.

CAMERON IT, BACON CR, COLLETT GP, DAVENPORT AP: Endothelin expression in the uterus. J Steroid Biochem Mol Biol 53: 209-214, 1995.

DAVENPORT AP: International Union of Pharmacology. XXIX. Update on endothelin receptor nomenclature. Pharmacol Rev 54: 219-226, 2002.

DAVENPORT AP, MAGUIRE JJ: Endothelin. Handb Exp Pharmacol 176: 295-329, 2006.

ENGELMANN TW: Zur physiologie des ureter. Pflugers Arch Gesamte Physiol Menschen Tiere 2: 243-293, 1869.

FELDMAN DL, MOGELESKY TC, CHOU M, JENG AY: Enhanced expression of renal endothelin-converting enzyme-1 and endothelin-A-receptor mRNA in rats with interstitial fibrosis following ureter ligation. J Cardiovasc Pharmacol 36: S255-S259, 2000.

HENRY PJ: Endothelin receptor distribution and function in the airways. Clin Exp Pharmacol Physiol 26: 162-167, 1999. 
HUANG SC: Endothelin receptors in gastrointestinal smooth muscle. Curr Protein Pept Sci 6: 547-557, 2005.

ISELIN CE, NY L, LARSSON B, SCHAAD NC, ALM P, GRABER P, MOREL DR, ANDERSSON KE: The nitric oxide synthase/nitric oxide and heme oxygenase/carbon monoxide pathways in the human ureter. Eur Urol 33: 214-221, 1998.

JANKOVIC SM, JANKOVIC SV, LUKIC G, CANOVIC D, FOLIC M: The contractile effects of endothelins on isolated isthmic segment of human oviduct at the luteal phase of the menstrual cycle. Methods Find Exp Clin Pharmacol 32: 91-95, 2010.

JANKOVIC SM, JANKOVIC SV, LUKIC G, RADONJIC V, CUPARA S, STEFANOVIC S: Contractile effects of endothelins on isolated ampullar segment of human oviduct in luteal phase of menstrual cycle. Pharmacol Res 59: 69-73, 2009.

JANKOVIC SM, MILOVANOVIC DR, JANKOVIC SV: Schild's equation and the best estimate of pA 2 value and dissociation constant of an antagonist. Croatian Med J 40: 67-70, 1999.

KENAKIN TP: The classification of drugs and drug receptors in isolated tissues. Pharmacol Rev 36: 165-222, 1984.

LAGHMANI K, PREISIG PA, MOE OW, YANAGISAWA M, ALPERN RJ: Endothelin-1/endothelin-B receptormediated increases in NHE3 activity in chronic metabolic acidosis. J Clin Invest 107: 1563-1569, 2001.

LANGENSTROER P, TANG R, DIVISH B, OPGENORTH T, SHAPIRO E, LEPOR H: Endothelins in canine genitourinary tissues. J Urol 157: 1044-1048, 1997.

LATIFPOUR J, FUKUMOTO Y, WEISS RM: Regional differences in the density and subtype specificity of endothelin receptors in rabbit urinary tract. Naunyn Schmiedebergs Arch Pharmacol 352: 459-468, 1995.

MAGNUS R: Versuche am überlebenden Dunndarm von Säugetieren. I. Mittheilung Pflügers Archiv 102: 123-151, 1904.

NAKAMURA I, SAITO M, FUKUMOTO Y, YOSHIDA M, NISHI K, WEISS RM, LATIFPOUR J: Experimental diabetes upregulates the expression of ureteral endothelin receptors. Peptides 18: 1091-1093, 1997.

OKAMOTO-KOIZUMI T, TAKEDA M, KOMEYAMA T, HATANO A, TAMAKI M, MIZUSAWA T, TSUTSUI T, OBARA K, TOMITA Y, ARAI K, TAKAHASHI K: Pharmacological and molecular biological evidence for $\mathrm{ET}_{\mathrm{A}}$ endothelin receptor subtype mediating mechanical responses in the detrusor smooth muscle of the human urinary bladder. Clin Sci (Lond) 96: 397-402, 1999.

PENG Y, AMEMIYA M, YANG X, FAN L, MOE OW, YIN H, PREISIG PA, YANAGISAWA M, ALPERN RJ: ET(B) receptor activation causes exocytic insertion of NHE3 in OKP cells. Am J Physiol Renal Physiol 280: F34-F42, 2001.

PINET F: What is the role of endothelin system? Med Sci (Paris) 20: 339-345, 2004.

POLIKEPAHAD S, MOORE RM, VENUGOPAL CS: Endothelins and airways - a short review. Res Commun Mol Pathol Pharmacol 119: 3-51, 2006.

SAITO M, WEISS RM, LATIFPOUR J: Effects of insulin treatment on diabetes-induced alterations in endothelin receptors in rat ureter. Int J Urol 6: 361-368, 1999.

SANTICIOLI P, MAGGI CA: Myogenic and neurogenic factors in the control of pyeloureteral motility and ureteral peristalsis. Pharmacol Rev 50: 683-721, 1998.

TAKEDA M, KOMEYAMA T, KOIZUMI T, HATANO A, TAMAKI M, TAKAHASHI H, TSUTSUI T, MIZUSAWA T, OBARA K: Endothelin receptors in the human urinary bladder are different from those in the human ureter. Clin Investig 72: 213, 1994.

TRAVAGLINI F, BARTOLETTI R, GACCI M, RIZZO M: Pathophysiology of reno-ureteral colic. Urol Int 72: 20-23, 2004.

UEHARA Y, BURNSTOCK G: Demonstration of 'gap junctions' between smooth muscle cells. J Cell Biol 44: 215 $220,1970$.

WADA Y, LATIFPOUR J, SANEMATSU H, AFIATPOUR P, WANG Z, SAITO M, NISHI K, WEISS RM: Agerelated changes in contractile responses of rabbit lower urinary tract to endothelin. J Urol 164: 806-813, 2000. 